\title{
APPLICATION BIPLOT ANALYSIS ON MAPPING OF NON-CONVERTIVE DISEASES IN INDONESIA
}

\author{
Kris Suryowati ${ }^{1}$, Maria Titah $\mathbf{J P}^{2}$, Nurzaidah Nasution ${ }^{3}$ \\ ${ }^{1,2,3}$ Institut Sains \& Teknologi AKPRIND Yogyakarta \\ *e-mail: suryowati@akprind.ac.id
}

\begin{abstract}
Non-communicable diseases is diseases that are not caused by germs but rather because of physiological or metabolic problems in human body tissues. Usually, this disease occurs due to unhealthy lifestyle. One way to find out how large the spread of non-communicable diseases is by mapping the disease using biplot analysis. Biplot analysis is applied to determine the proximity information between objects, the length of the change vector, the correlation between modifiers, and the value of the change in an object. The study was conducted in 33 provinces with twelve noncommunicable diseases. Descriptive analysis of twelve non-communicable diseases averaged the highest joint disease of 10.51 followed by hypertensive disease 8.85 and Stroke 6.42. While the lowest average disease is Heart Failure disease by 0.10 it is still open to research with other methods and also need to add supporting variables
\end{abstract}

Keywords: Biplot Analysis, Non-Communicable Diseases.

Cite: Suryowati K., JP, M. T., \& Nasution, N. (2021). Application Biplot Analysis on Mapping of Non-Convertive Diseases in Indonesia. Parameter: Journal of Statistics, 1(2), 11-20.

Copyright (C) 2021 Suryowati et al. This is an open-access article distributed under the Creative Commons Attribution License, which permits unrestricted use, distribution, and reproduction in any medium, provided the original work is properly cited. 


\section{INTRODUCTION}

Multivariate analysis is a statistical technique that is applied to understand the structure of data in high dimensions, where the variables in question are related to one another. One of the interpretations of multivariate analysis is to look at the relationship between objects, between variables, and between objects and variables that are displayed in two dimensions. The more variables that are measured, the more objects will be observed. As a result, the size of the table that is owned will be difficult to interpret. Therefore, we need a method that makes it easier to interpret the data we have. One of the multivariate methods that can be used to overcome this problem is the biplot method.

The biplot is an attempt to describe the data in the summary table in a two-dimensional graph (Leleury \& Wokanubun, 2015). The information provided by the biplot includes objects and variables in one image. Biplot analysis is descriptive with two dimensions that can visually present $\mathrm{n}$ objects of observation and variables in a graph in the form of a flat plane. This analysis is used to determine the closeness between objects, the diversity between variables, the correlation between variables and the value of variables on the object. With a presentation like this, the characteristics of the variables and objects of observation as well as the relative positions between the objects and the variables can be analyzed. The biplot method has been widely used in various fields, one of which is in the health sector. As time goes by, the health problems faced are also increasingly diverse, for example noncommunicable diseases. One way to find out how to deal with non-communicable diseases in Indonesia is through data. Through data, it can be seen how much the spread of non-communicable diseases is by mapping the non-communicable diseases. In this case, a biplot analysis is applied to map the non-communicable diseases that are often faced in Indonesia by obtaining a picture of both their diversity and correlation. The morbidity and mortality rates caused by non-communicable diseases tend to increase. Changes in disease patterns are strongly influenced by changes in the environment, community behavior, demographic, socio-economic and cultural transitions.

Non-communicable diseases (PTM) are known as chronic diseases that are not transmitted from person to person. Putri \& Nanang (2020), The progression of non-communicable diseases is generally slow and requires a long duration. The World Health Organization (WHO) has determined the types of PTM that need immediate attention and treatment, namely cardiovascular disease (coronary heart disease, stroke), cancer, chronic respiratory disease (asthma and chronic obstructive pulmonary disease), and Diabetes Mellitus (DM). The development of PTM in Indonesia has not been well assessed, due to the absence of systematic data that is routinely obtained in stages and is integrated both across programs and across sectors at the regional and national levels.

Several previous studies showed that the biplot analysis method was applied to several studies including Biplot Analysis on Mapping Characteristics of Poverty in Maluku Province (Leleury \& Wokanubun, 2015), Biplot Analysis Approach to the Description of Relative Position Between SMAs in Denpasar City (Melissa, 2012), Biplot Analysis on Characteristics Mapping Poverty in North Sulawesi Province (Padang, et al., 2019), and Grouping of Ultra Hight Tempherature Milk Brands Based on Nutritional Content Using Biplot Analysis and apart from biplot analysis (Putri \& Nanang, 2020), Pat analysis can also be applied such as in Logistic Regression and Path Analysis Method to Analyze Factors influencing Students Achievement (Noeryanti, et al., 2018).

Therefore, this study discusses a biplot analysis of quantitative data on non-communicable diseases in Indonesia based on Basic Health Research (Riskesdas) data. The variables used in this study were asthma, Chronic Obstructive Pulmonary Disease (COPD), cancer, Diabetes Mellitus (DM), hyperthyroidism, hypertension, coronary heart disease, heart failure, stroke, chronic kidney failure (CRF), kidney stones, and rheumatism. Based on the description of non-communicable diseases in Indonesia from Riskedas data, it will be seen the analysis of the mapping results of non-communicable diseases in Indonesia based on the biplot.

\section{MATERIAL AND METHOD}

The biplot analysis method has different indicators, this can be seen in the results of research conducted by Leleury \& Wokanubun (2015), Melissa (2012), Padang, et al. (2019), and Putri \& Nanang, (2020). Therefore, in this study using biplot analysis, to apply to the mapping of NonCommunicable Diseases in Indonesia, both diversity and correlation, so that it can be presented directly the defining variable or dominant variable of an object formed in the mapping of noncommunicable diseases. The scope of biplot analysis is to provide an overview of the data in a two- 
dimensional graph. The information provided by the biplot includes object and variable information in a single image. The research objects are described as points in the biplot graph so that it can be seen the closeness between the research objects, in this case the proximity between the types of noncommunicable diseases in Indonesia. While the variables will be described in a vector which is used to determine the diversity of variables and the correlation between variables.

This study uses secondary data, Basic Health Research data (RISKESDAS). The variables used in this study were adjusted to the available data (RISKESDAS), namely twelve infectious diseases including asthma $\left(\mathrm{X}_{1}\right)$, chronic obstructive pulmonary disease $\left(\mathrm{X}_{2}\right)$, cancer $\left(\mathrm{X}_{3}\right)$, diabetes mellitus $\left(\mathrm{X}_{4}\right)$, hyperteroid $\left(\mathrm{X}_{5}\right)$, hypertension $\left(\mathrm{X}_{6}\right)$, coronary heart $\left(\mathrm{X}_{7}\right)$, heart failure $\left(\mathrm{X}_{8}\right)$, stroke $\left(\mathrm{X}_{9}\right)$, chronic renal failure $\left(\mathrm{X}_{10}\right)$, kidney stones $\left(\mathrm{X}_{11}\right)$, joint disease / rheumatism $\left(\mathrm{X}_{12}\right)$.

Biplot analysis is a multivariate method that uses rows and columns in a graph used to display objects and variables with the object under study Leleury \& Wokanubun (2015), Padang, et al. (2019). Biplot is a multiple variable technique that presents a plot of observations of $n$ and $p$ variables simultaneously on a plane. Presentation of plots of observations of $n$ and $p$ variables simultaneously to provide additional information that is better for the relationship between variables and observations.

There are four important pieces of information obtained from the biplot display, including:

1. The proximity between objects or the proximity of two objects is interpreted as the similarity in the properties of the two objects. The closer the two objects are, the more similar the properties shown by the variable values are.

2. The length of the variable vector is proportional to the variability of the variable, where the variable with a small diversity value will be described as a vector, while the variable with a high diversity value will be described as a long vector

3. Correlation between variables is two variables that have a positive correlation value $(+)$ which is described as two lines in the same direction or forming an acute angle. Two variables that have a negative correlation value are described as two lines in opposite directions or forming an obtuse angle. The two uncorrelated variables are represented as straight lines with angles approaching 900 (right)

4. The value of a variable on an object is an object that is located in the direction of the variable vector that has a value above the average. Conversely, objects that are located opposite the direction of the variable vector have a value below the average. The variable value on an object is used to see the characteristic variables of each object. The value of the variables in an object can be seen by doing an orthogonal projection of the object to the variable vector.

Calculations in biplot analysis are based on Singular Value Decompotion (SVD). The Matrix $X_{(n \times p)}$ where $\mathrm{n}$ is the number of objects of observation and $\mathrm{p}$ is the number of variables. then the matrix can be written as:

$$
X=U L A^{\prime}
$$

Matrix $U$ is ortonormal column matrix $\left(U^{\prime} U=A^{\prime} A=I\right)$ and matrix $L$ is diagonal matrix at ordo $(r \times r)$ where the diagonal elements are the root of (Suryowati \& Harmastuti, 2013) the eigenvalues $X^{\prime} X$ ie $\sqrt{\lambda_{1}} \geq \sqrt{\lambda_{2}} \geq \cdots \geq \sqrt{\lambda_{r}}$. The diagonal elements of the matrix $\mathrm{L}$ are called the singular values of the matrix $X$ and the matrix column $A$ is the eigenvector of $X^{\prime} X$ which corresponds to $\lambda$. The columns for the matrix $\mathrm{U}$ are obtained from $u_{i}=\frac{1}{\sqrt{\lambda_{i}}} a_{i}, i=1,2, \cdots, r, u_{i}$ : column matrix $U, a_{i}$ : column matrix $A$ dan $\lambda_{i}$ : the singular values ie.i. $L^{\alpha}$ with $0 \leq \alpha \leq 1$ is diagonal matrix at ordo $r \times r$ of diagonal elements $\sqrt{\lambda_{1}^{\alpha}} \geq \sqrt{\lambda_{2}{ }^{\alpha}} \geq \cdots \geq \sqrt{\lambda_{r}^{\alpha}}$, and this definition applies to $L^{1-\alpha}$ for the diagonal elemens are $\sqrt{\lambda_{1}{ }^{1-\alpha}} \geq \sqrt{\lambda_{2}{ }^{1-\alpha}} \geq \cdots \geq \sqrt{\lambda_{r}{ }^{1-\alpha}}$.

The $\alpha$ value in the matrix $L$ is the singular value of the $X$ matrix which will be adjusted into $L^{\alpha}$ and $L^{1-\alpha}$ such that $L^{\alpha} L^{1-\alpha}=L$. The range of $\alpha$ values is $0 \leq \alpha \leq 1$ satisfies i $L^{0}=I$ and $L^{1}=L$, Suppose $F=U L^{\alpha}$ and $G^{\prime}=L^{1-\alpha} A^{\prime}$. From equation (1) so that it is obtained

$$
\begin{aligned}
X & =U L A \\
& =U L^{\alpha} L^{1-\alpha} A^{\prime} \\
& =F G^{\prime}
\end{aligned}
$$

For the element $\mathrm{i}, \mathrm{j}$ matrix $\mathrm{X}$ can be written as: 


$$
X_{i j}=f_{i} g_{j}
$$

where $\mathrm{i}=1,2,3, \cdots, \mathrm{n}$ and $\mathrm{j}=1,2,3, \cdots, \mathrm{p}$ and, respectively. The $\mathrm{f} \_\mathrm{i}$ and $\mathrm{g} \mathrm{j}$ have $\mathrm{r}$ dimensions. If $X$ has a rank of two, the row vector [f]] $\mathrm{i}$ and the column vector $\mathrm{g}_{-} \mathrm{j}$ can be represented with certainty in two-dimensional space. If $\mathrm{X}$ has a higher rank, the equation (1) becomes:

where $i=1,2,3, \cdots, n$ is the row of the matrix $\mathrm{F}$ and $j=1,2,3, \cdots, p$ is the column of the matrix G. Pada $f_{i}$ dan $g_{j}$ have is $r$ dimensions. If $X$ has a rank of two, the row vector $f_{i}$ and the column vector $g_{j}$ can be represented with certainty in two-dimensional space. If $X$ has a higher rank equation (1) becomes

$$
x_{i j}=\sum_{k=1}^{r} u_{i k} \lambda_{k}^{\frac{1}{2}} a_{j k}^{\prime}
$$

Where $u_{i k}$ is the element $\mathrm{i}, \mathrm{k}$ of matrix $U, a_{j k}^{\prime}$ is the $\mathrm{j}$ th element $\mathrm{k}$ of the matrix and $\lambda_{k}^{\frac{1}{2}}$ is the k-th diagonal element of matrikx $L$. The original data set consisting of $\mathrm{n}$ objects and $\mathrm{p}$ variables is reduced to a data set consisting of $n$ objects with the first $m$ elements. If there are $m$ as many elements as preserved, equation (3) can be approximated by:

$$
\begin{aligned}
x_{i j} & =\sum_{k=1}^{r} u_{i k} \lambda_{k}^{\frac{1}{2}} a_{j k}^{\prime}, \quad m<r \\
& =\sum_{k=1}^{r} u_{i k}\left(\lambda_{k}^{\alpha}\right)^{\frac{1}{2}}\left(\lambda_{k}^{1-\alpha}\right)^{\frac{1}{2}} a_{j k}^{\prime} \\
& =\sum_{k=1}^{r} f_{i k} g_{j k}^{\prime} \\
& =f_{i}^{* \prime} g_{j}^{*}
\end{aligned}
$$

Where $f_{i}^{* \prime}$ and $g_{j}^{*}$ each element contains a vector element $f_{i}$ dan $g_{j}$. Gabriel (1971) in Padang, et al. (2019) and Putri \& Nanang (2020) states that $\mathrm{m}=2$ is called a biplot, so that equation (5) can be expressed as,

$$
{ }_{2} x_{i j}=f_{i}^{* \prime} g_{j}^{*}
$$

${ }_{2} x_{i j}$ is an element of the $\mathrm{X}$ matrix approach in two dimensions, while $f_{i}^{* \prime} g_{j}^{*}$ each contains the first two elements of the vectors $f_{i}$ dan $g_{j}$.

From the $\mathrm{X}$ matrix approach in the second dimension, the F and $\mathrm{G}$ matrices are obtained as follows:

$$
F=\left[\begin{array}{cc}
f_{11} & f_{12} \\
\vdots & \vdots \\
f_{i 1} & f_{i 2} \\
\vdots & \vdots \\
f_{n 1} & f_{n 2}
\end{array}\right], G=\left[\begin{array}{cc}
g_{11} & g_{12} \\
\vdots & \vdots \\
g_{i 1} & g_{i 2} \\
\vdots & \vdots \\
g_{n 1} & g_{n 2}
\end{array}\right]
$$

To describe the biplot, , it is necessary to take the $\alpha$ dalam mendefenisikan value in defining $F$ and $G$. The selection of $\alpha$ values at $\alpha$ at $F=U L^{\alpha}$ and $G=L^{1-\alpha} A^{\prime}$ 'is arbitrary with the condition $0 \leq \alpha \leq 1$. Taking the extreme values $\alpha=0$ and $\alpha=1$ is useful in biplot interpretation

If $\alpha=0$ then $F=U L^{0}=U$ and $G=L^{1} A^{\prime}=A L$, so

$$
\begin{aligned}
X^{\prime} X & =(F G)^{\prime}\left(F G^{\prime}\right) \\
& =G F^{\prime} F G^{\prime} \\
& =G U^{\prime} U G^{\prime} \\
& =G G^{\prime}
\end{aligned}
$$

$U$ is orthogonal, while $X^{\prime} X=G G^{\prime}=(n-1) S, S$ is the covariance matrix of the sample. So that the product $g_{j} g^{\prime}{ }_{k}$ be equal to $(n-1)$ times the covariance $S_{j k}$ and $g_{j} g^{\prime}{ }_{k}$ to be represents the $-k$ th covariance. Therefore the correlation between the $j$ vareable and the $k$ variable is indicated by cosine value betwaan the vector $g_{j}$ and $g_{k}$. To determina the variation of the variables used the matrix $G G$ '. 


$$
\begin{aligned}
G G^{\prime} & =\left[\begin{array}{cc}
g_{11} & g_{12} \\
\vdots & \vdots \\
g_{p 1} & g_{p 2}
\end{array}\right]\left[\begin{array}{lll}
g_{11} & \cdots & g_{p 1} \\
g_{12} & \cdots & g_{p 2}
\end{array}\right] \\
& =\left[\begin{array}{ccc}
g_{11}^{2}+g_{12}^{2} & \cdots & g_{11} g_{p 1}+g_{12} g_{p 2} \\
\vdots & \ddots & \vdots \\
g_{11} g_{p 1}+g_{12} g_{p 2} & \cdots & g_{p 1}^{2}+g_{p 2}^{2}
\end{array}\right]
\end{aligned}
$$

The main diagonal of the matrix $G G^{\prime}: g_{11}^{2}+g_{12}^{2}, \cdots, g_{j 1}^{2}+g_{j 2}^{2}, \cdots, g_{p 1}^{2}+g_{p 2}^{2}$ describes the variance of the variable. Whereas $g_{j 1}^{2}+g_{j 2}^{2}, j=1,2, \cdots, n$ denotes the length of the variable vector with the euclide distance from the point $(0,0)$. So it can be concluded that the length of the variable vector is proportional to the variation of the variable

The cosine of the angle between the two vector variables illustrates the correlation of the two variables. The smaller the angle between the two variables, the higher the correlation. The following is the calculation of the angular cosine of the vectors $g_{j}$ and $g_{k}$.

$$
\begin{aligned}
& S_{j j}=\left|g_{j}\right|\left|g_{k}\right| \cos \theta \\
& \cos \theta=\frac{S_{j k}}{\left\|g_{j}\right\|\left\|g_{k}\right\|}=\frac{S_{j k}}{\sqrt{S_{j j}} \sqrt{S_{k k}}}=\frac{S_{j k}}{S_{j} S_{k}}=r_{j k}
\end{aligned}
$$

Where is $S_{j k}$ : covariance of the $k$-th vareable and $r_{j k}$ : correlation of the k-variable

\section{RESULTS AND DISCUSSION}

Based on the results of descriptive analysis (Setyawan et al., 2018) and using Minitab software,

\begin{tabular}{|c|c|c|c|c|}
\hline Variabel & Mean & Min & Max & $\begin{array}{l}\text { Standard } \\
\text { Deviation } \\
\end{array}$ \\
\hline Asthma & 4,59 & 1,6 & 7,8 & 1,63 \\
\hline chronic obstructive pulmonary disease (COPD) & 4,07 & 1,4 & 10 & 1,83 \\
\hline Cancer & 1,31 & 0,2 & 4,1 & 0,69 \\
\hline diabetes mellitus & 1,41 & 0,7 & 2,6 & 0,53 \\
\hline Hiperteroid & 0,32 & 0,1 & 0,7 & 0,16 \\
\hline Hypertension & 8,85 & 3,2 & 15 & 0,44 \\
\hline coronary heart & 0,43 & 0,2 & 0,8 & 0,17 \\
\hline heart failure & 0,10 & 0,02 & 0,3 & 0,050 \\
\hline Stroke & 6,42 & 2.3 & 10,8 & 2,16 \\
\hline chronic renal failure & 0,23 & 0,1 & 0,5 & 0,10 \\
\hline kidney stones & 0,5 & 0,1 & 1,2 & 2,23 \\
\hline Rheumatism & 10,51 & 5,6 & 19,3 & 3,43 \\
\hline
\end{tabular}
it can be seen in table 1 below. Data overview of non-communicable diseases (PTM) in Indonesia This descriptive analysis aims to determine the diversity of PTM for all variables to be studied.

Table 1. Descriptive Analysis

Table 1 shows that the variable that has the highest average disease is Joint Disease 10.51 followed by Hypertension, 8.85 and Stroke, 6.42. Meanwhile, the lowest disease average was Heart Failure at 0.10. The lowest prevalence of non-communicable diseases was Heart Failure 0.02 and the highest was Joint Disease 19.3. The standard deviation value is used to calculate the standardization of the data. In the data, the provinces with the highest average disease are in the provinces of North Sulawesi and Central Sulawesi with a prevalence value of 4.3 and the lowest is Riau province with a prevalence value of 2.0.

Biplot analysis is based on determining the singular value of a data matrix that has been corrected by its mean, for the original data matrix. Determination of the singular value of the $\mathrm{X}$-order matrix to be a matrix $U$ of ordo $n \times r$, matrix $L$ of ordo $r \times r$ and matrix $A$ of ordo $r \times p$, which is corrected for its mean. In this study, with the object of observation as many as 33 provinces and 12 variables declared the types of diseases consisting of 12 non-communicable diseases. Calculation of eigenvalues, proportions and cumulatives based on calculations using Minitab software is presented in table 2 below: 
Table 2. The eigen value, proportion, and cumulative in non-communicable diseases

\begin{tabular}{lccc}
\hline \multicolumn{1}{c}{ Variable } & $\begin{array}{c}\text { Nila } \\
\text { Eigen } \\
\text { value }\end{array}$ & Proportion & cumulative \\
\hline Asthma & 5,5003 & 0,458 & 0,458 \\
chronic obstructive pulmonary disease & 2,3362 & 0,195 & 0,653 \\
Cancer & 1,3474 & 0,112 & 0,765 \\
diabetes mellitus & 0,9084 & 0,076 & 0,841 \\
Hiperteroid & 0,5314 & 0,044 & 0,885 \\
Hypertension & 0,4289 & 0,036 & 0,921 \\
coronary heart & 0,2875 & 0,024 & 0,945 \\
heart failure & 0,2515 & 0,021 & 0,966 \\
Stroke & 0,1534 & 0,013 & 0,979 \\
chronic renal failure & 0,1274 & 0,011 & 0,989 \\
kidney stones & 0,0700 & 0,006 & 0,995 \\
Rheumatism & 0,0576 & 0,005 & 1,000 \\
\hline
\end{tabular}

After decomposing the singular value on the $\mathrm{X}$ matrix, the biplot construction is done by making $F$ and $G$ matrix where the $F$ matrix is the coordinate point of 33 objects and the $G$ matrix is the coordinate point of the 12 variables. The $\mathrm{F}$ and $\mathrm{G}$ matrices are obtained through equation (3) using $\alpha=$ 1 , then $\mathrm{F}=\mathrm{UL}$ and $\mathrm{H}^{\prime}=\mathrm{A}^{\prime}$. From the matrix approach to the two-dimensional matrix $\mathrm{F}$ and $\mathrm{H}$, it is obtained by taking the first two columns from the $\mathrm{F}$ matrix and the first two rows from the $\mathrm{H}$ matrix.

Table 3. Biplot Coordinates for Objects in Dimension 1 and Dimension 2 (F)

\begin{tabular}{|c|c|c|c|}
\hline No. & Province & Dimension 1 & Dimension 2 \\
\hline 1 & Aceh & 1,88467 & 1,681658 \\
\hline 2 & Sumatera Utara & $-0,63642$ & $-1,33328$ \\
\hline 3 & Sumatera Barat & 0,114809 & $-1,03436$ \\
\hline 4 & Riau & $-3,28833$ & $-1,83453$ \\
\hline 5 & Jambi & $-2,45852$ & $-0,89461$ \\
\hline 6 & Sumatera Selatan & $-2,70357$ & $-1,14116$ \\
\hline 7 & Bengkulu & $-1,29389$ & $-1,3996$ \\
\hline 8 & Lampung & $-2,56065$ & $-0,19466$ \\
\hline 9 & Bangka Belitung & 0,455327 & $-2,13387$ \\
\hline 10 & Kepulauan Riau & $-0,4752$ & $-2,44304$ \\
\hline 11 & DKI Jakarta & 3,137213 & $-2,15938$ \\
\hline 12 & Jawa Barat & 1,541594 & 1,448522 \\
\hline 13 & Jawa Tengah & 2,306027 & $-0,37509$ \\
\hline 14 & DI Yogyakarta & 6,613997 & $-1,7148$ \\
\hline 15 & Jawa Timur & 3,098523 & $-0,46917$ \\
\hline 16 & Banten & $-0,54127$ & $-0,60268$ \\
\hline 17 & Bali & 0,81277 & 1,198119 \\
\hline 18 & Nusa Tenggara Barat & $-2,79765$ & 0,66295 \\
\hline 19 & Nusa Tenggara Timur & 0,083507 & 3,583229 \\
\hline 20 & Kalimantan Barat & $-2,1084$ & 0,217487 \\
\hline 21 & Kalimantan Tengah & $-0,91863$ & 0,821781 \\
\hline 22 & Kalimantah Selatan & 0,867956 & 0,120586 \\
\hline 23 & Kalimantan Timur & 0,608945 & $-1,91201$ \\
\hline 24 & Sulawesi Utara & 4,011964 & $-0,57493$ \\
\hline 25 & Sulawesi Tengah & 3,147788 & 3,209068 \\
\hline 26 & Sulawesi Selatan & 1,734389 & 1,365523 \\
\hline 27 & Sulawesi Tenggara & $-1,11587$ & 1,096489 \\
\hline
\end{tabular}


Table 4. Biplot Coordinates for Objects in Dimension 1 and Dimension 2 (F) (continued)

\begin{tabular}{llcc}
\hline No. & Province & Dimension 1 & Dimension 2 \\
\hline 28 & Gorontalo & 0,542347 & 1,572472 \\
29 & Sulawesi Barat & $-1,21014$ & 0,852093 \\
30 & Maluku & $-1,24907$ & 0,508835 \\
31 & Maluku Utara & $-2,11461$ & 0,359555 \\
32 & Papua Barat & $-2,67234$ & $-0,4912$ \\
33 & Papua & $-2,81727$ & 2,010019 \\
\hline
\end{tabular}

Table 5. Biplot Coordinates for Variables in Dimension 1 and Dimension $2(\mathrm{G})$

\begin{tabular}{lcc}
\hline \multicolumn{1}{c}{ Variable } & Dimension 1 & Dimension 2 \\
\hline Asthma & 0,220013 & 0,401445 \\
chronic obstructive pulmonary disease & 0,063234 & 0,531179 \\
Cancer & 0,29251 & $-0,2295$ \\
diabetes mellitus & 0,360245 & $-0,20966$ \\
Hiperteroid & 0,373268 & $-0,01214$ \\
Hypertension & 0,343791 & $-0,02135$ \\
coronary heart & 0,345049 & $-0,02955$ \\
heart failure & 0,29596 & $-0,18464$ \\
Stroke & 0,348002 & $-0,22604$ \\
chronic renal failure & 0,226485 & 0,392475 \\
kidney stones & 0,307451 & 0,23916 \\
Rheumatism & 0,034031 & 0,402698 \\
\hline
\end{tabular}

After obtaining the object coordinate points and variable coordinate points, the F and $\mathrm{G}$ matrix are depicted in two dimensions with the object and research variables adjusted to these dimensions

Based on the biplot analysis procedure, the results obtained using R studio software as in Figure 1 below:

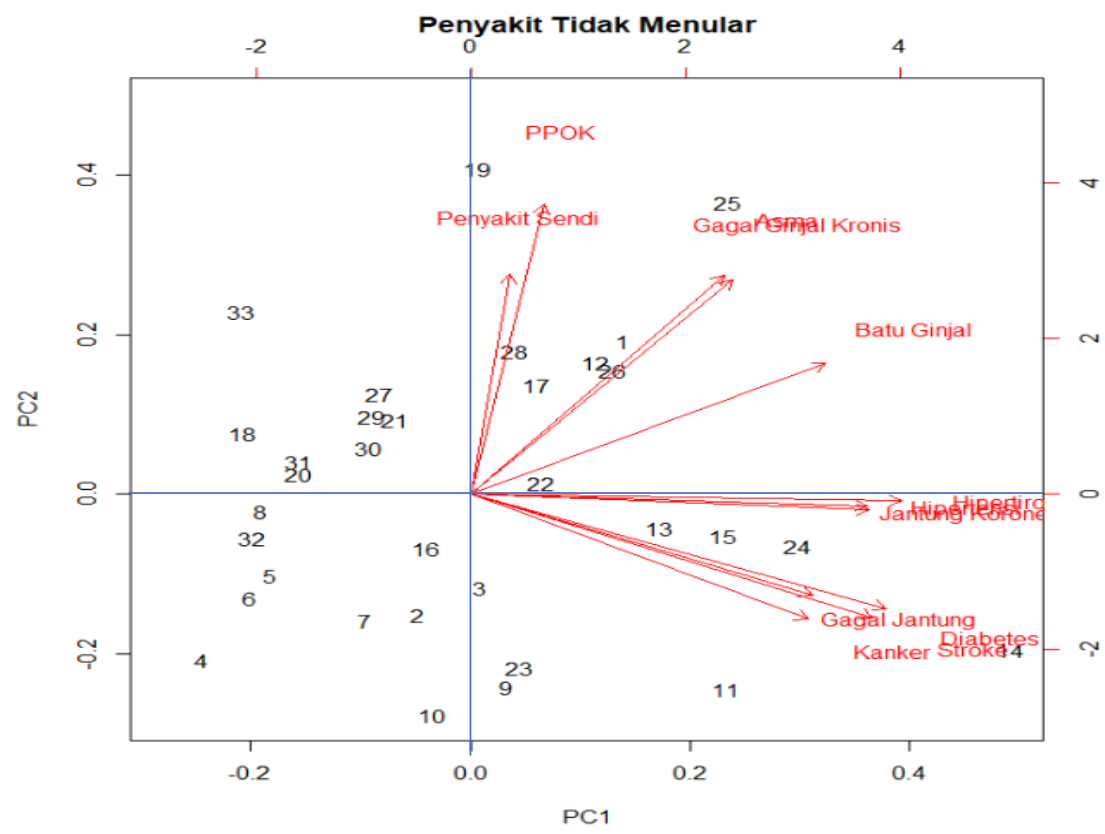

Figure 1. Biplot Graph of Non-Communicable Diseases in Indonesia 
The interpretation of the Biplot Graph includes the closeness between objects, variable values, and variable diversity. The explanation of each is as follows:

The similarity in characteristics of variables can be explained based on the location of the quadrant, where if it is located in the same quadrant, it has the same characteristics. Based on Figure 1, the similarity of characteristics between objects, namely provinces that have similar characteristics, are as follows,

1. Quadrant I, the provinces of Aceh, Bali, NTT, Central Sulawesi, South Sulawesi and Gorontalo have the same characteristics.

2. Quadrant II, the provinces of NTB, West Kalimantan, Central Kalimantan, Southeast Sulawesi, Maluku, North Maluku and Papua have the same similarities.

3. Quadrant III, the provinces of North Sumatra, Riau, Jambi, South Sumatra, Bengkulu, Lampung, Banten and West Papua have the same similarities.

4. Quadrant IV, the provinces of West Sumatra, Bangka Belitung, DKI Jakarta, Central Java, DI Yogyakarta, East Java, East Kalimantan, and North Sulawesi have the same proximity

In the Biplot Graph Figure 1 is used to see the relationship of each province to noncommunicable diseases. Provinces that are located in the direction of the non-communicable disease vector indicate that these provinces have a large number of non-communicable diseases. However, if a province is located in the opposite direction to a non-communicable disease vector, then the province has a small number of non-communicable diseases. Meanwhile, provinces which are relatively in the same direction have almost the same number of non-communicable diseases. Based on Figure 1 it can be explained as follows,

1. Aceh Province, West Java, Bali, East Nusa Tenggara, South Kalimantan, Central Sulawesi and South Sulawesi provinces have a variety of asthma $\left(\mathrm{X}_{1}\right)$, COPD $\left(\mathrm{X}_{2}\right)$, kidney failure $\left(\mathrm{X}_{10}\right)$, kidney stones $\left(\mathrm{X}_{11}\right)$, and other diseases. joints $\left(\mathrm{X}_{12}\right)$.

2. West Sumatra, Bangka Belitung, DKI Jakarta, Central Java, DI Yogyakarta, East Java, East Kalimantan, and North Sulawesi provinces have various diseases such as hyperthyroidism $\left(\mathrm{X}_{5}\right)$, hypertension $\left(\mathrm{X}_{6}\right)$, coronary heart $\left(\mathrm{X}_{7}\right)$, heart failure $\left(\mathrm{X}_{8}\right)$, DM $\left(\mathrm{X}_{4}\right)$, cancer $\left(\mathrm{X}_{3}\right)$, and stroke $\left(\mathrm{X}_{9}\right)$.

The diversity of non-communicable diseases in Indonesia can be explained in Figure 1, which is shown by the vector length criteria. Based on Figure 1, the variable with a large diversity is described as a long vector, and a small diversity is represented by a short vector. The vector length data for each variable, based on the calculation hassle, obtained in Table 5 as follows,

Table 6. Value of the vector length of each variable

\begin{tabular}{lc}
\hline \multicolumn{1}{c}{ Variable } & Length vector \\
\hline Asthma & 0,4578 \\
chronic obstructive pulmonary disease & 0,5349 \\
Cancer & 0,3718 \\
diabetes mellitus & 0,4168 \\
Hiperteroid & 0,3735 \\
Hypertension & 0,3445 \\
coronary heart & 0,3463 \\
heart failure & 0,3488 \\
Stroke & 0,415 \\
chronic renal failure & 0,4531 \\
kidney stones & 0,895 \\
Rheumatism & 0,4041
\end{tabular}

From Figure 1 and Table 5 above, it can be seen that the variable vector COPD $\left(\mathrm{X}_{2}\right)$ has the longest vector. This shows that the value of $\operatorname{COPD}\left(\mathrm{X}_{2}\right)$ in non-communicable diseases has the greatest diversity. Meanwhile, the shortest variable vector is hypertension $\left(\mathrm{X}_{6}\right)$. This shows that the variety of hypertension variables $\left(\mathrm{X}_{6}\right)$ in non-communicable diseases is the smallest. The correlation between 
vareables is explained by the angle formed between the variable vectors. Two vectors that have a high correlation will be represented as two vector lines forming a narrow angle. If the angle is perpendicular then the two are uncorrelated. Meanwhile, if the angle isobtuse, the correlation is lower, and if it is in the opposite direction, the correlation is negative. Based on the calculation, the cosine value between variables through equation (8) is presented in table form below:

Table 7. Angle $\theta$ between variables

\begin{tabular}{|c|c|c|c|c|c|c|c|c|c|c|c|c|}
\hline Variable & $X_{1}$ & $X_{2}$ & $X_{3}$ & $X_{4}$ & $\mathbf{X}_{5}$ & $X_{6}$ & $X_{7}$ & $\mathrm{X}_{8}$ & $X_{9}$ & $X_{10}$ & $X_{11}$ & $X_{12}$ \\
\hline $\mathrm{X}_{1}$ & $90^{\circ}$ & & & & & & & & & & & \\
\hline $\mathrm{X}_{2}$ & $21,94^{\circ}$ & $90^{\circ}$ & & & & & & & & & & \\
\hline$X_{3}$ & $99,39^{\circ}$ & $121,33^{\circ}$ & $90^{\circ}$ & & & & & & & & & \\
\hline $\mathrm{X}_{4}$ & $91,47^{\circ}$ & $113,41^{\circ}$ & $7,92^{\circ}$ & $90^{\circ}$ & & & & & & & & \\
\hline $\mathrm{X}_{5}$ & $63,14^{\circ}$ & $85,07^{\circ}$ & $36,25^{\circ}$ & $28,34^{\circ}$ & $90^{\circ}$ & & & & & & & \\
\hline$X_{6}$ & $64,83^{\circ}$ & $86,76^{\circ}$ & $34,56^{\circ}$ & $26,65^{\circ}$ & $1,69^{\circ}$ & $90^{\circ}$ & & & & & & \\
\hline $\mathrm{X}_{7}$ & $66,17^{\circ}$ & $88,11^{\circ}$ & $33,22^{\circ}$ & $25,31^{\circ}$ & $3,03^{\circ}$ & $1,34^{\circ}$ & $90^{\circ}$ & & & & & \\
\hline $\mathrm{X}_{8}$ & $93,23^{\circ}$ & $115,17^{\circ}$ & $6,16^{\circ}$ & $1,76^{\circ}$ & $30,10^{\circ}$ & $28,41^{\circ}$ & $27,07^{\circ}$ & $90^{\circ}$ & & & & \\
\hline $\mathrm{X}_{9}$ & $94,28^{\circ}$ & $116,22^{\circ}$ & $5,11^{\circ}$ & $2,81^{\circ}$ & $31,14^{\circ}$ & $29,45^{\circ}$ & $28,11^{\circ}$ & $1,05^{\circ}$ & $90^{\circ}$ & & & \\
\hline$X_{10}$ & $1,26^{\circ}$ & $23,20^{\circ}$ & $98,13^{\circ}$ & $90,21^{\circ}$ & $61,88^{\circ}$ & $63,57^{\circ}$ & $64,91^{\circ}$ & $91,97^{\circ}$ & $93,02^{\circ}$ & $90^{\circ}$ & & \\
\hline$X_{11}$ & $23,40^{\circ}$ & $45,33^{\circ}$ & $76,00^{\circ}$ & $68,08^{\circ}$ & $39,74^{\circ}$ & $41,43^{\circ}$ & $42,77^{\circ}$ & $69,84^{\circ}$ & $70,88^{\circ}$ & $22,133^{\circ}$ & $90^{\circ}$ & \\
\hline $\mathrm{X}_{12}$ & $23,89^{\circ}$ & $1,96^{\circ \circ}$ & $123,29^{\circ}$ & $115,37^{\circ}$ & $87,03^{\circ}$ & $88,72^{\circ}$ & $90,06^{\circ}$ & $117,13^{\circ}$ & $118,17^{\circ}$ & $25,157^{\circ}$ & $47,29^{\circ}$ & $90^{\circ}$ \\
\hline
\end{tabular}

Table 6 shows that the variable vector of chronic renal failure $\left(\mathrm{X}_{10}\right)$ has an acute angle with the asthma vector variable $\left(\mathrm{X}_{1}\right)$. This indicates that the two variables have a high correlation with the angle formed by $1.26^{\circ}$, both of these variables have a strong degree of closeness. The joint disease vector variable $\left(\mathrm{X}_{12}\right)$ has an obtuse angle (opposite direction) to the heart failure variable vector $\left(\mathrm{X}_{8}\right)$. This indicates that the two variables have a low correlation with the angle formed by $117.13^{\circ}$, the two variables have a low level of closeness.

\section{CONCLUSION}

Based on the results of the analysis and discussion of non-communicable diseases in Indonesia using a biplot analysis, it is concluded that the highest average non-communicable disease is joint disease 10.51 is found in Bali province, and the lowest average disease is heart failure 0.10 is found in North Maluku province. Based on the biplot graph, it can be interpreted as follows regions that have the same characteristics are divided into four, namely in quadrant I of Aceh, Bali, NTT, Central Sulawesi, South Sulawesi, and Gorontalo provinces which have the same characteristics. And it has Quadrant II: NTB, West Kalimantan, Central Kalimantan, Southeast Sulawesi, Maluku, North Maluku and Papua provinces have similar similarities. Quadrant III North Sumatra, Riau, Jambi, South Sumatra, Bengkulu, Lampung, Banten, and West Papua provinces have the same similarities. Quadrant IV: The provinces of West Sumatra, Bangka Belitung, DKI Jakarta, Central Java, DI Yogyakarta, East Java, East Kalimantan and North Sulawesi have the same proximity.

The provinces of Aceh, West Java, Bali, East Nusa Tenggara, South Kalimantan, Central Sulawesi and South Sulawesi have a variety of asthma, COPD, kidney failure, kidney stones, and joint diseases. Meanwhile, the provinces of West Sumatra, Bangka Belitung, DKI Jakarta, Central Java, DI Yogyakarta, East Java, East Kalimantan and North Sulawesi have various non-communicable diseases such as hyperthyroidism, hypertension, coronary heart disease, heart failure, diabetes mellitus, cancer and stroke. COPD disease has the greatest diversity and the shortest variable vector is hypertension, which shows that the variation of hypertension variables is the smallest.

\section{REFERENCES}

Leleury, Z. A., \& Wokanubun, A. E. (2015). Analisis Biplot pada Pemetaan Karakteristik Kemiskinan di Provinsi Maluku. Barekeng: Jurnal ilmu matematika dan terapan, 9(1), 21-31.

Melissa, M. (2012) Pendekatan Analisis Biplot Dalam Mendeskripsikan Posisi Relatif Antar SMA Di Kota Denpasar. E-Jurnal Matematika. Vol. 1, No.1, p 47-51 
Noeryanti, Suryowati, K., \& Setyawan,Y. (2018). Logistic Regression and Path Analysis Method to AnalyzeFactors influencing Students' Achievement. IOP Conf. Series: Materials Science and Engineering 335 (2018) 012044 doi:10.1088/1757-899X/335/1/012044

Padang, D. L., Rindengan, A. J., \& Kekenusa, J. S. (2019). Analisis Biplot pada Pemetaan Karakteristik Kemiskinan di Provinsi Sulawesi Utara. d'CARTESIAN, 8(1), 49-52.

Putri, S., \& Nanang, A. (2020). Pengelompokan Merek Susu Ultra Hight Tempherature Berdasarkan Kandungan Gizi Menggunakan Analisis Biplot..e-journal unp

Setyawan, Y., Noeryanti, Suryowati, K. (2018). Statistika Dasar Dilengkapi dengan Software R. Yogyakarta.

Suryowati, K., \& Harmastuti, (2013), Aljabar Linear, Akprind press, Yogyakarta

https://lokadata.beritagar.id/chart/preview/prevalensi-asma-menurut-provinsi-2018-1555042135\#. (Diakses pada 13 November 2019)

http://labdata.litbang.kemkes.go.id/images/download/laporan/RKD/2013/RKD dalam angka final.pd f, Riset Kesehatan Dasar (RISKESDAS) 2013 (Diakses pada 23 Februari 2018)

2019. Manajemen Penyakit Tidak Menular, Jakarta, KEMENKES Direktorat Jendral Pencegahan dan Pengendalian Penyakit.

2018. Profil Kesehatan Indonesia, Jakarta, Kementerian Kesehatan Indonesia. 